\title{
Cannes International Film Festival 2000
}

\author{
By Ron Holloway
}

Fall 2000 Issue of KINEMA

\section{REVOLUTION ON THE CROISETTE}

Scandinavia was a clear winner at Cannes 2000. But the revolution on the Croisette took place elsewhere.

After Lars von Trier's remarkable run of five previous entries (four times competing) in the Official Program -- to wit: Element of Crime (1984), Epidemic (1987) (selected for the Certain Regard), Europa (1991), Breaking the Waves (1996) (runner-up Grand Jury Prize), and Idiots (1998) -- the Danish director finally received the Golden Palm he so well deserved for Dancer in the Dark. Arguably he should have won it back in 1996 for Breaking the Waves and certainly he was the talk of the 1998 festival for proclaiming the merits of "Dogma Manifesto" to all and sundry who would listen to this magnificent ploy. No matter, this time Dancer in the Dark was the clear favourite from the very moment the film packed the Salle Lumière for the 8:30 press screening on a Wednesday morning four days before the close of the festival.

Originally Björk, the Icelandic pop star, was signed to compose the musical score for Dancer in the Dark. Then, by some stroke of good fortune, von Trier persuaded her to play the lead role of Selma, a Czech immigrant working extra shifts at a factory somewhere in rural America -- read provincial Sweden, for von Trier is afraid of flying. About to go blind from an hereditary eye disease, Selma needs every penny she can save for an operation to rescue her 10-year-old son from the same fate. When her savings are stolen by a neighbour, the web of fate tightens until, quite unintentionally, she commits a murder. Brought to trial and found guilty, Selma chooses capital punishment in order to sacrifice herself for her son. Awarded Best Actress, Björk confessed at Cannes to difficulties with both the role and the director, so much so that she swore at the press conference that she would never act in a film again.

This said, it should be maintained nonetheless that Dancer in the Dark stands up as a unique film experience. And for several reasons. First of all, in making this $\$ 15$ million international co-production Lars von Trier has forsaken his rather specious Dogma principles altogether, opting instead to direct "a musical melodrama that collides with reality." Further, supporting performances by Catherine Deneuve and Joel Gray are laudatory, although generally wasted. Finally, von Trier has renewed his creative association with ace cinematographer Robbie Müller (Breaking the Waves) to shoot most of the film with Sony digital cameras, employing for the dance sequences alone a score of PD100 cameras. These dream-like numbers are stunning, to say the least. In fact, coupled with Björk's input, it would be hard to find a parallel in film history to match the outdoor, naturalistic, choreographic breadth of Dancer in the Dark -- a quasi-musical version of Breaking the Waves.

For the first time in the history of the Cannes film festival, Hollywood productions were conspicuously absent -- and scarcely missed by critics and audiences alike. Indeed, the awarding of Best Screenplay to John C. Richards and James Flamberg for Nurse Betty (USA) seemed more like an afterthought on the part of the international jury, particularly as director Neil LaBute is an auteur in his own right -- originally a playwright, his two prior films, In the Company of Men (1997) and Your Friends and Neighbours (1998), rate as scathing satires on the American experience. As for this black comedy about a Kansas waitress (Renée Zellweger) obsessed with a soap opera serial and pursued to LA by hitmen was penned by a standup comedian (Richards) and a music editor (Flamberg). Its best moments are all too familiar: Nurse Betty comes across as the flip-side of Woody Allen's Purple Rose of Cairo (1985 Cannes entry).

Freed of Hollywood hoopla, cineastes could revel in European talent, embrace discoveries from the East, welcome Independents from around the world, and voice guarded hopes for new names and styles and trends. Sweden, for instance, was present with a pair of appealing competition entries. Ingmar Bergman's screenplay for Liv Ullmann's Trolöse (Unfaithful) proved to be a windfall for actress Lena Enore: she gives a refined, tempered, moving performance as the adulterous wife. And Roy Andersson's weird, absurd, Kafkaesque Sånger från andra våningen (Songs from the Second Floor) shared the Jury Prize -- for many, it provided an offbeat moment of sheer viewing pleasure. 
France, present with four films in competition -- to say nothing of another in the Certain Regard, plus a special screening of an Agnes Varda documentary, and Roland Joffé's sumptuous Vatel to open the festival (a French production by a British director set in the court of Louis XIV and shot in English) -- hardly needed a jury prize to boot. Over all these towered the singular talent in Dominik Moll, whose Harry, un ami qui vous veut du bien (Harry, He's Here to Help) drew warm critical recognition for its Hitchcockian twists and Buñuelian jabs at bourgeois morality. No less an astute observer than Gilles Jacob proclaimed 2000 as "the best season for French cinema since 15 years," and he was seconded in that regard by Marie-Pierre Macia of the Directors Fortnight ( 8 features, 7 shorts) and José Maria Riba of the Week of the Critics (2 features, 2 shorts) -- to say nothing of the half-dozen French co-productions scattered throughout all the sections.

No one was really surprised when talented offspring of the prominent were singled out for awards. Rodrigo Garcia, son of writer Gabriel Garcia Marques, received the "Certain Regard" Award for Things You Can Tell Just by Looking at Her (USA), a neatly intertwined collection of five vignettes probing entangled relationships narrated from a reserved, perceptive standpoint. Samira Makhmalbaf, daughter of Iranian director Mohsen Makhmalbaf, was awarded a share of the Jury Prize for Takhté siah (Blackboards) (Iran-Italy-GermanyJapan), a half-poetic, half-neorealist sketch of harsh conditions among Kurds on the Iranian-Iraqi border as viewed through the experiences of itinerant teachers with sign-boards on their backs in search of students.

Cannes 2000 will go down in festival history as a veritable feast of Asian cinema -- altogether 20 feature films (15 in the official program alone) by directors with roots in Asia, most from the Far East. South Korea alone was present with an entry in each of the four main sections. Further, 13 jury prizes were awarded to features and shorts from China, Hong Kong, Taiwan, Japan, Iran, India, Vietnam, Israel, and the Philippines. The runner-up Grand Jury Prize went to actor-director Jiang Wen's Guizi lai le (Devils on the Doorstep, China), who himself plays a lead role in this political satire set in an occupied Chinese village towards the end of the war in 1945. Edward Yang rightly deserved Best Director for Yi Yi (A One and a Two, Taiwan), a richly detailed family saga that scored as one of the highlights of the festival. Tony Leung was awarded Best Actor for his role in Wong Kar-wai's In the Mood for Love (Hong Kong-China), in addition to art director William Chang Suk-Ping sharing the Grand Technical Prize. Indeed, In the Mood for Love, set in Hong Kong of the 1960s, surely ranks as one of the most subtly sophisticated erotic Asian films ever made.

Asian fever also gripped the other key juries at the festival. The Camera d'Or was shared by a pair of Iranian first filmmakers: Hassan Yekpatanah for Djomeh (Iran-France) in the Certain Regard and Bahman Ghobadi for Zamani barayé masti asbha (A Time of Drunken Horses, Iran) in the Directors Fortnight. A Time for Drunken Horses was also awarded a FIPRESCI (International Critics) Prize. Another double winner was Shinji Aoyama's Eureka (Japan-France): the competition entry received both the International Critics (FIPRESCI) Prize and the Ecumenical Award. Moreover, the FIPRESCI Jury at its press conference saluted "the extraordinary dynamism of Asian cinema as represented in the official selection of the festival." In short, the FIPRESCI Jury proclaimed a revolution of aesthetic taste, of production trends, of new film styles on the Croisette. And rightly so. Cannes may never be the same again.

"This film is a sort of prayer for modern man, who is searching for the courage to go on living," said Aoyama about Eureka in an interview. "A crime is committed suddenly, as if it were a natural disaster. It changes the lives of three people, who formerly led lives that were quite normal. It is as though they are pursued by an endless tidal wave preventing them from regaining their balanced lives. On the edge of despair, they take off for a voyage of resurrection."

Sound a bit familiar? Then take the director on his word: Eureka drew its thematic strength from The Searchers (1956), a John Ford classic. In fact, the final scene in Eureka is almost a direct quote from the closing minutes of The Searchers, the scene in which John Wayne turns to Natalie Wood to say "let's go home" ... to start life all over again. "In my earlier films, I told stories that juxtaposed social misfits, each under the burden of that particular psychological baggage of postwar Japan. With Eureka I add to my body of work a prayer for life and the desire to be reborn."

As unfamiliar as his name sounded to the uninitiated at Cannes, Shinji Aoyama is anything but unknown on the festival circuit. His films have been invited to Locarno, Rotterdam, Torino, Toronto, and the Viennale, to say nothing of being awarded at home the Grand Prix of the Japanese Film Industry Professional Awards for his debut feature Helpless (1995). An independent filmmaker to the core, he is involved in nearly every 
major aspect of a production -- from It's Not in the Textbook (1995), a straight-to-video project, and Helpless (1995) to Two Punks (1996), Wild Life (1997), An Obsession (1997), Shady Grove (1999), and now Eureka.

Born 1964 in Kita-Kyushu, Shinji Aoyama studied at Rikkyo University, where, influenced by Shingehiko Hasumi's lectures on film criticism, he began to make $8 \mathrm{~mm}$ films: Straight to the Night and The Red Muffler. Upon graduating, he entered the film industry as a prop assistant, then rose to assistant director (Kiyoshi Kurosawa's The Guard from the Underground). Meanwhile, he contributed essays and criticism to Cahiers du Cinema (Japan) and Esquire (Japan). Aoyama also worked as assistant director on Fridrik Thor Fridriksson's Cold Fever (1995), the story of a Japanese youth journeying to Iceland to fulfill a burial ritual and thus pay due respect to his deceased parents, and assisted Swiss director Daniel Schmid on The Written Face (1995), a made-in-Japan feature that offers insights for Western viewers into the traditions of Kabuki theatre and geisha performers.

Aoyama surpasses the output of his colleagues in the current New Japanese Cinema movement by a creative tour-de-force: he wrote, directed, edited, and composed the music for Eureka, a three-and-a-half-hour low-budget road-movie with improvised twists and turns in the casual story line. The setting is Kyushu in southwest Japan, where on a hot summer morning a municipal bus is hijacked and only three people survive the carnage: the driver Makoto (Koji Yakusho, familiar to Cannes audiences for playing the lead in Shohei Imamura's The Eel, the 1997 Golden Palm co-winner), the girl Kozue (Aoi Miyazaki), and her older brother Naoki (Masaru Miyazaki). Traumatized, the driver disappears. As for the children, they recede into themselves, then experience a further shock when their mother divorces and their father dies. Two years later, Makoto returns to become the children's surrogate father, and the family clan is joined by their cousin, a college student on vacation.

Another twist of fate proves just as unsettling as the first catastrophic blow. The body of a woman is discovered, murdered, and Makoto is suspected. So he buys an old bus, outfits it with beds, and "the four" set off on a prolonged journey." The number four has an important place in Eureka" confirms Shinji. "There are four principal players and four tombs in the front yard. Four is a number that moves the wheels of destiny -- at least in the first part of the film. In Japanese, the number four is pronounced 'shi', which could also signify death. The number four could also stand for the traditional family (two parents, two children). In the last twenty years, family tradition has all but disintegrated, and the ideal number -- four -- has become meaningless."

Shot in black-and-white, sepia-tone cinemascope, Eureka takes its title from a Jim O'Rourke rock album. Tipped by the director as both an "inward road movie" and a "western tracing the journey of a soul" (thus the comparison with The Searchers, the John Ford classic), it is a multi-textured film that speaks to both the painful reality of contemporary Japan and the calamities suffered worldwide wherever the moral order is in evident disintegration. Its inspiration came from the recent sarin gas attack in the Tokyo subway and a rise in senseless violent crimes in Japan. Of all the remarkable entries at Cannes 2000, Eureka was, indeed, a film for the new millennium.

\section{Notes on Veteran Directors in the Competition}

Gohatto (Taboo, Japan), by Nagisa Oshima.

Nagisa Oshima, the one great living Cannes legend, was back on the Croisette with Gohatto after a 14-year absence from directing a feature film. Veteran Cannes festivaliers look back with nostalgia to that famous 1968 "broken" festival, when Oshima in a show of solidarity sided with rebellious students and a phalanx of French auteur directors (Jean-Luc Godard, François Truffaut) to dramatically announce the withdrawal of his Japanese entry Death by Hanging from the main program. One year later, in 1969, Pierre-Henri Deleau invited Oshima to participate in the Directors Fortnight, the newly founded alternative festival housed in the Cinéma Le Français on the Rue d-Antibes. He came with The Diary of a Shinjuku Burglar, while Death by Hanging was given an honorary showing in a sidebar.

Oshima returned to the Directors Fortnight again in 1971 with The Ceremony, and he was back in 1976 with one of the most memorable film events Cannes has ever seen: In the Realm of the Senses, acclaimed by critics as a chef d'oeuvre and by the crowds storming the theatres as one of the most important, if not the best, erotic film ever made. The story doesn't end there. In 1978, shortly after Gilles Jacob had left his job as critic at $L^{\prime}$ Express to succeed Maurice Bessy as director of the Cannes festival, he invited Nagisa Oshima 
to show his Empire of the Passion in the competition, a reflective, philosophical sequel to In the Realm of the Senses -- and Oshima was awarded Best Director. Jacob invited him back to Cannes in 1983 with Merry Christmas, Mr. Lawrence, starring an Oshima discovery, Takeshi "Beat" Kitano. And there he was again in 1986 with Max My Love, a French production remarkable for its wit and light comic touches.

"I have spent all my life breaking taboos," stated Nagisa Oshima frankly in an interview. Born 1932 in Kyoto -- his short film Kyoto, My Mother's Place (1991) focuses on his childhood -- he obtained a degree in law at Kyoto University in 1954, then joined the Shochiku Studios in Tokyo to assist several directors (Hideo Oba) and make a handful of short films. His first feature film, A Town of Love and Hope (1959), sketches the tender relationship of a poor pigeon vendor with a young girl from the middle class and ends on a note of shocking brutality -- too much for the guardians of public morality, and the "scandal" could only be shown in selected venues. He followed in 1960 with three strong feature films in quick succession: Naked Youth (1960), about the miserable existence of young people in a decadent modern society that won him the Best Newcomer Prize by the Japanese Directors Guild. Then came The Sun's Burial, acclaimed as the standard-bearer of the Japanese New Wave and awarded again by his peers. But it was Night and Fog in Japan that ended his relationship with the studio system: a portrayal of the assassinated socialist leader Inejiro Asanuma with an added statement on political agitation in Japan, it was banned after four days in release.

Oshima founded his own Sozosha ("Creation") production company in 1961. The first feature to appear was The Catch (1961), adapted from Kenzburo Oe's novel, followed by documentaries, telefeatures, and a string of dynamic, fast-paced, low-budget films for both television and cinema screens: The Revolt (1962), Yunbogi's Diary (1964), The Pleasures of the Flesh (1965), The Daylight Demon (1966), The Band of Ninja (1967), Sing a Song of Sex (1967), Japanese Summer: Double Suicide (1967), Death by Hanging (1968), Three Resurrected Drunkards (1968), Diary of a Shinjuko Burglar (1969), Boy (1969), The Man Who Left His Will on Film (1970), Ceremony (1971), Dear Summer Sister (1972) -- many of which were presented a decade ago in an all-embracing Nagisa Oshima retrospective at Filmfest München.

Held back by a heart condition, Nagisa Oshima has struggled to find international backing for his large-scale projects. "I wanted to made a film in the United States, Hollywood Zen, about the meeting of the actors Sessue Hayakawa and Rudolph Valentino. "So I decided to direct again a Japanese film with a decent budget," he confirmed in an interview, "but this project failed at the last minute for financial reasons. That's when I decided to go back to Japan to make a film with a more reasonable budget -- and that film was Gohatto. Unfortunately, after I made the announcement that I was going ahead with this film, I had a stroke and had to take a three year break." Gohatto (better translated as "The Rule" than as "Taboo"), set in 1865, is about the fall of the Shogun Tokugawa and the restoration of the Meiji Emperor. "When I was a child, I was fascinated by this period and by the Shinsengumi, a group of samurai opposed to the restoration of the Meiji."

This being the end of the samurai epoch, a popular theme in Japanese cinema, the film probes some reasons for the tragedy of samurai sacrificing themselves for the weak and disintegrating Tokugawa rulers. "When you have a group of men," Oshima points out, "there always exists some aspect of homosexuality" -- the taboo theme that lends Gohatto its specific attraction and, if you will, radical political statement.

Fast Food, Fast Women (France-USA-Germany-Italy), Amos Kollek.

"I remember where the idea for Fast Food, Fast Women came from," recalled Amos Kollek in an interview. "Two or three years ago, I had this thought that it would be nice to open a place, sort of a restaurant, where there would be food and women easily available. Like a MacDonald's with sex appeal. Of course, it was more of a joke than a real plan, because I am not in the restaurant business. But when I wrote the script, I incorporated it, and particularly the title. I actually do think that a place called Fast Food, Fast Women, possibly a chain, has some business potential."

Novelist, screenwriter, actor, documentarist, director, producer -- no one knows the twists and turns of filmmaking, from the inside out, from concept to release, better than Amos Kollek. "I like to go my own way," he says, adding on a note of light irony: "And I prefer to work with people I like. Not a secret, nor a dogma, nor a rule of thumb -- but a credo." 
Born 1947 in Jerusalem, Amos Kollek has always gone his own way. Son of the eminent mayor of Jerusalem, Teddy Kollek, Amos had to do just that if he ever hoped to leave the shadow of one of the most popular figures on the Israeli political scene. From 1965 to 1968, he served in the Israeli army during one of the decisive moments in his country's history: the Arab-Israeli war of 1967. In 1971, he received a BA in Psychology and Philosophy at the Hebrew University in Jerusalem. That same year, he published his first novel, "Don't Ask Me If I Love" and was given the Evans Award for Fiction. Three more novels followed at regular intervals: "The Girl Who Brought the War" (1973), "After They Hanged Him" (1976), and "The Apple, the Singing and the Gold" (1980). In between, he collaborated with his father on a personal biography, "For Jerusalem, A Life" (1979), to be capped later by the companion documentary Teddy Kollek (1994). And along the way, he contributed articles to Ma'ariv, La'Isha, Jerusalem Post, New York Times, and Die Zeit in Germany.

Amos Kollek admits to a restless streak. "My style has changed over the years," he will answer with candour to an honest estimate of his considerable talents. "What else can I say ... see for yourself." His latest novel, "4 Weeks in Gaza" (1995), translated and published in Germany, is one of his favourites because "it's something new and goes in a different direction." Much the same can be said about his filmmaking career -- as actor, screenwriter, director, producer. In other words, if the challenge is there, if it's interesting and fun, if it's not going to take months or years to see a project through, then he's liable to shake the tree to see how the apples fall.

His film career began in the triple-decker pattern of actor, screenwriter, and co-producer on Worlds Apart (1979). To these credits he added director on Goodbye, New York (1984), starring Julie Hagerty; Forever Lulu (1987), with Hanna Schygulla and Alec Baldwin; High Stakes (1989), with Sally Kirkland and Kathy Bates; Double Edge (1994), with Faye Dunaway; and Whore 2 (Bad Girls) (1994), produced by Julian Schlossberg. Favourite films during this period? Link Goodbye, New York with Double Edge and Bad Girls to note a distinct progression in his personal style as a writer-director.

The international breakthrough came with Sue (1997), starring Anna Thomson. It won the FIPRESCI (International Critics) Award and the Ecumenical Award at the 1998 Berlinale, followed by a Special Acting Award for Anna Thomson at the Montreal festival. A year later, Kollek and Thomson were back again in the Panorama of the Berlinale with Fiona (1999), a hard-edge, half-fiction, half-documentary sequel to Sue that focussed on the demimonde of the Manhattan crack-house scene. And, of course, Anna Thomson can be seen again in Kollek's new feature film, Fast Food, Fast Women.

"It was a thrill to work with Anna Thomson on a comedy for a change," says Amos Kollek. "It was also fun in general to work on an 'up' movie. It gave me the chance to work, among others, with Louise Lasser, who appeared in some of the early Woody Allen movies. I'm a fan of Woody Allen." The setting is a Manhattan coffee shop, where overworked waitress Bella (Anna Thomson) isn't exactly looking forward to her 35th birthday. Tired of her long-standing affair with a married man, she latches on to Bruno (Jamie Harris), a would-be novelist driving a taxi, and tries to bluff her way through the relationship with some tall stories. "The film incorporates characters of different ages, people looking for love." After all, a Manhattan coffee shop is per se a place visited by limber lotharios, merry widows, and old guys falling for young strippers -a haunt for fairy tales that sometimes come true.

Kippur (Israel-France-Italy, 2000), by Amos Gitai.

Competing for the Golden Palm for the second year in a row, following Kadosh (Sacred) in 1999, Israeli director Amos Gitai was backed by the same producers and made use of virtually the same production crew for Kippur, an action thriller drawn from an autobiographical experience: the beginning of the Israeli-Arab war in October of 1973 (aka the Yom Kippur War). Renato Berti is again the cameraman, Monica Coleman the editor, Miguel Markin the art director, Laura Dinulasco the costume designer, and so on down the line. If there's a moral to be found there, then it's the benefits that can be drawn from commitment and loyalty.

Amos Gitai is one of those festival personalities who commands attention with each film he makes. Back in 1986, his Esther, an Israeli-French co-production lensed partially by the eminent French cinematographer Henri Alekan, was invited to participate at Cannes in the Week of the Critics. A few years later, when he collaborated again with Alekan and Israeli cinematographer Nuritz Aviv on Berlin Jerusalem (France 1989), about the emigration of German writer Else Lasker-Schüler to Israel with Lisa Kreuzer in the lead role, the film was invited to Venice. 
The hat-trick of adding Berlin to the string of Gitai/Alekan festival triumphs came in 1991, when their Golem, the Spirit of Exil (France, 1991), a cross-European co-production about exiles and emigrants, premiered at the 1992 International Forum of Young Cinema as part of a four-film tribute to the director. Starring Hanna Schygulla, she was supported by such screen and stage luminaries as Samuel Fuller, Bernardo Bertolucci, Marceline Loridan, Philippe Garrel, Sotigui Kouyate (Peter Brooks ensemble), and Antonio Carallo (Pina Bausch Dance Company). That film completed a trilogy on exile and emigration.

"In fact, all my films focus on exile," confirmed Amos Gitai in an interview, "be it inner exile or the exile of a people displaced in space or time, like this community which brings us back to reflections of the past" -- in reference to the volatile subject matter in Kadosh, shot in Mea Shearim, Jerusalem's ultra-orthodox Jewish quarter, where tourists are often attacked on the streets because of affronts to the accepted dress code. And he added: "It is through fiction that I am able to show the contradictions inherent in these communities' imperviousness to our times."

Born 1950 in Haifa, Amos Gitai is the son of Munio Gitai, a member of the prewar Bauhaus in Germany. He studied architecture in Haifa and at the University of California Berkeley and was wounded in action in the Yom Kippur War -- which does a long way to explain why he was interested in making a film on the subject. "When I'd paid my debts to my family spirits," Gitai said in a an interview published in Cinemaya, "I felt I was free to make films. I never studied cinema formally. But I think not studying cinema helped me a great deal, because films are so inter-referential today. I find architecture and cinema have a lot in common -- because they are not intimate arts like writing or painting.. You have to mobilize other people."

Gitai's interest in filmmaking stems back to Super-8 films and some documentaries. One of his documentaries made for Israeli TV, Bait (The House, 1977), was not aired on the grounds that it was too pro-Palestinian. It portrayed three families -- Jewish, Arab, and a Jewish-Arab couple -- all living together in the Wadi Rushmia river valley east of Haifa.

Fiction or not, Amos Gitai's films are always based on fact and thorough research of the subject matter. In his widely praised documentary on The Wadi 1981-1991 he explored over a decade the possibilities and impossibilities of full integration between countless social fractions in Israel within the microcosm of a Haifa slum. In the feature film Devarim (1995), presented at Venice, he adapted a well known Hebrew novel to the screen in such a way as to weigh the contradictions within modern-day Tel Aviv life. Much the same holds true for Kadosh (1999), a portrait of the city of Jerusalem as well as an oppressive Jewish Orthodox community.

Kippur opens on 8 October 1973 -- Yom Kippur, the Day of Atonement. Throughout the film we follow in the footsteps of Amos "Weinraub" Gitai. At the very beginning of the Israeli-Syrian conflict, a helicopter is hit by a missile and shot down behind Syrian lines. In the helicopter is a seven-man rescue team, among them Amos Gitai. As related in the film, this was a closely knit unit comprised of individuals from different backgrounds. Some died, others were seriously wounded, one (Amos Gitai) was hospitalized for a time. By the time the war ended on 11 October 1973, over 12,000 died on Israeli and Arab sides, more than 25,000 were wounded, and nearly 10,000 had been taken prisoners. Kippur offers the human side of the Yom Kippur War in this fiction-documentary with Livan Levo as writer-director Amos Gitai.

Code Inconnu (Code Unknown, France-Germany), Michael Haneke.

"It's always very hard, impossible even, for me to sum up in a few sentences this 'thing' which ends up becoming something strangely complex, and on which one has spent most of one's time and energy for the past year and a half," summarizes Michael Haneke in his usual enigmatic way about the making of Code Inconnu. And he adds: 'Moreover, I think that, even more so than in my other films, Code Unknown resists this process and is harder to reduce to a single 'theme'. I think that, by reducing it to its most obvious ideas -- the Babylonian confusion of languages, the incapacity to communicate, the coldness of the consumer society, xenophobia, etc. -- we cannot avoid a mere string of clichés."

Sound cryptic? Michael Haneke has always felt that his psychodramas have to be seen rather than spoken about. Born 1942, he studied philosophy, psychology, and theatre in Vienna. After working for a time for German television (1967-70), he launched off on his own in 1970 as an independent writer-director. Meanwhile, he exercised his other chosen profession of stage director in Austria and Germany. 
Approximately half of Haneke's written-and-directed telefeatures are literary adaptations: After Liverpool (1974), based on James Saunders's play; Three Ways to the Sea, adapted from an Ingeborg Bachmann novel; Who Was Edgar Allan? (1984), taken from a novel by Peter Rosel; The Rebellion (1993), based on a Joseph Roth novel; and The Castle (1997) adapted from a Franz Kafka novel -- the last named a cinema film and programmed at the International Forum of Young Cinema. As for the other telefeatures -- Big Garbage (1974), Lemmings I \& II (1979), Variation (1983), Fräulein (1985), and Testimonial for a Murderer (1991) -- these can generally be categorized under the psychodramas -- or, if you will, psychological studies of pathological cases -- that form his vision as an original auteur.

Discovered for Cannes by Pierre-Henri Deleau, Michael Haneke is best known for his trilogy of psychological studies presented in the Directors Fortnight, each dealing with emotionally disturbed individuals representative of a morally ruptured society. In these films people have lost both the ability, even the desire, to communicate -- the phenomenon of "glaciation," as Haneke terms it. In The Seventh Continent (1989) deranged parents lock themselves into their apartment, poison their daughter, and then commit a double suicide. In Benny's Video (1992), self-centered middle-class parents attempt to cover up a senseless murder committed by their lonely teenaged son, who is living a stunted childhood with his camcorder and has completely lost touch with reality. In 71 Fragments of a Chronology of Chance (1994) an emotionally disturbed university student opens fire with a gun in a bank randomly killing a number of people he doesn't even know.

When Haneke completed this trilogy with a coda, Funny Games (1997), chosen for the competition at Cannes, it became a cause célèbre by virtue of the shock effect that rippled through the audience and drove the hypersensitive from their seats. The weird tale of a pair of murderous psychopaths who appear suddenly on the scene at a vacation villa, the members of a family are first driven to the limits of an emotional breakdown before the murders are actually committed -- after which the lunatics move on to their next victims.

Queried in an interview as to whether these films also criticized the way contemporary reality is portrayed in movies, Haneke agreed: "It becomes a sine qua non for every filmmaker in the age of media manipulation. I can't take anybody quite seriously if their work doesn't reflect that. You can't act as if you were still in the 19 th century and as if reality could be reduced in its entirety. That's absurd. But that's what approximately 90 percent of all directors do. People want to be reassured, not forced to think. But the purpose of art has always been to question the status quo."

Ask about the inspiration behind Code Unknown, Haneke responded in an interview: "It all started with Juliette Binoche, who called one day and asked if we could work together. I've always wanted to make a film about modern-day migration ... as a result of different factors, though the primary reasons were and are economic, the disparity between rich and poor. There are already two cities in Europe where this fact is obvious, and where a truly multicultural society has developed. One of them is Paris."

Code Unknown opens on a busy boulevard in Paris with a crumpled piece of paper dropped into the outstretched hands of a beggar-woman. Anne (Juliette Binoche), a young actress, is about to become a star in the cinema. Her boyfriend, a war photographer, is hardly at home, whose younger brother has no interest in taking over their father's farm. Add to these an African music teacher at a deaf-mute institute, a beggar from Romania fearful of being deported, and a handful of other multicultural characters, and you are confronted with (so Haneke fears) the Babylonian confusion of languages, the incapacity to communicate, the coldness of the consumer society, xenophobia, and other movie clichés he labours to break.

La Noce (The Wedding, France-Germany-Russia), Pavel Lungin.

Asked to contribute to "Les Visiteurs de Cannes", a special publication for the festival's 1995 cinema centennial celebrations, Pavel Lungin ("Lounguine," if you prefer the French transliteration from Cyrillic letters) chose to pen an essay titled "History Before My Window" -- about the aborted coup in Moscow to overthrow Mikhail Gorbachev on 21 August 1991. "The tanks rolled down the street and constructed a barricade under my windows. It is erected with a lot of savoir-faire, as though these people had been doing it all their lives. There had been shots the night before, and the first victims were being counted. Cannes, with its grand staircase and its red carpet, with its breakfasts under the tents on the beach, with its crowds gathering daily for the festivities, all this seemed today to be not only unreal but also a bit indecent." 
Born 1949 in Moscow of Russian and French nationality, Pavel Lungin graduated from the Department of Structural Linguistics at Moscow University, then enrolled in 1973 at the Moscow Film school (VGIK) for a two-year course in Screenplay Writing. He is one of two prominent Mosfilm screenwriters -- Sergei Bodrov is the other -- who broke the barrier separating writers and directors in Russian film production to become an auteur in his own right -- the sort of radically combined writer-director that Goskino officials feared and detested during the heyday of socialist realism. In fact, their film careers are remarkably similar.

In the case of Sergei Bodrov, he was born 1948 in Khabarovsk (Siberia), studied first at the Moscow Institute for Energetics, then in 1971 joined the Screenplay Writing faculty at the Moscow Film School (VGIK). He penned over 30 screenplays for other directors until 1984, when he was collaborating with Kazakh director Amanbek Alpiyev on the feature Sweet Dreams in the Grass and noticed cases of unused film laying around after the production was completed. From this unused footage, and with the co-operation of friends on the film crew, he directed The Non-Professionals (1985) -- and saw it promptly shelved by Goskino. Two years later, during the early perestroika (reconstruction) days, it was given its first screening among the "Forbidden Films" programmed at Dom Kino during the Moscow film festival -- and was invited to the 1988 International Forum of Young Cinema at the Berlinale. Sergei Bodrov was suddenly in demand as a film director.

Pavel Lungin experienced the same stroke of luck. For 15 years, from 1974 to 1989, he wrote a score of scripts for others and saw most of them badly directed. When MK2, a French production company, was considering possible French-Russian co-production projects at the Lenfilm Studios, they hit upon Pavel Lungin's screenplay for Taxi Blues. And since Lungin is as proficient in French as in Russian -- to say nothing of his deep respect for French culture -- he was given the option to bring his own script to the screen as a debut director. Taxi Driver was selected for the competition at the 1990 Cannes festival, contended for Camera d'Or honours, and was awarded the Best Director prize. The story of a love-hate relationship, it depicts an encounter between a pair of opposites, a taxi-driver loner interested only in money and a Jewish alcoholic musician, that eventually ends in tragedy.

In a statement Pavel Lungin clarified his position on suddenly being hailed as one of Russia's first auteur directors: "I don't believe at all in the 'artist' -- I believe in his 'work'. The 'artist' is an ordinary person, with his complexes, his vanity, and his ambitions. I am sure that $m y$ world and $m y$ manner of viewing things are not more interesting than life itself. When I shoot a film, I am completely detached. And if the results are good, some forces are coming from elsewhere -- in other words, this energy from somewhere else goes through me as though I am being guided by a 'current' (of inspiration)."

This interest in viewing life and places in close-up brought Pavel Lungin to the documentary film. After Taxi Blues made Gulag -- Secret of Happiness (1991), followed by three other documentaries: Nice -- The Little Russia (1993) (about you know where), The Eskimos -- Unnecessary People (1994), and a portrait of Vladimir Mayakovsky (1998). In between, he made the features Luna Park (1992), Lifeline (1996), and now La Noce (The Wedding).

Luna Park, invited to compete at the 1992 Cannes festival, takes the pulse of the nationalist movement in Moscow and other major cities in Russia. Described by Lungin as "a journey through post-perestroika" Moscow," the film focuses on Andrei, a young nationalist leader, who heads a gang armed with clubs to vent their rage. Since Andrei doesn't know who is father is, he wants to know the truth from his mother -- and is more than shocked to discover that his father is a Jew.

In The Wedding, set in a small mining town near Moscow, Mishka (Marat Bakharov) is preparing to marry Tanya (Maria Mironova), his childhood sweetheart. His parents, however, are of a different opinion about a girl who has returned from a prolonged stay in Moscow and won't say much about what she did there. As the wedding day approaches and the guest list grows, Tanya's former shady lover suddenly appears on the scene -- now rumours are more rampant than ever about this "creature from the den of iniquity." Mishka's father, hailed as a local hero, is furious. Mishka's mother sheds tears over the lad's future. Mishka is bracing for a showdown. A tragicomedy packed with critical comment and unexpected humorous twists, The Wedding comes across as an accurate and disturbing mirror to current affairs in provincial Russia.

Estorvo (Turbulence, Brazil-Portugal-Cuba), Ruy Guerra. 
To say that Ruy Guerra was one of the pioneers of the Brazilian Cinema Novo movement of the 1960s would be to minimize the importance of this world figure who has directed some 30 films in South America, Europe, and Africa. In addition, he has scripted or co-scripted nearly all his films, has worked as a film editor and cinematographer, has acted in the films of others on occasion (he could be seen in Werner Herzog's Aguirre, Wrath of God, shot in the Amazones of Brazil), and usually produces himself every film he sincerely believes in. Moreover, he has worked as a film critic and journalist, publishes stories and chronicles, is a playwright and directs stage productions, collaborates with several renown Brazilian musicians as a songwriter, and presently teaches at the School of Cinema at Gama Fiho University in Rio de Janeiro. Most important of all, particularly for his filmmaking career, Ruy Guerra is a political activist.

Born 1931 in Lourenço Marques (today Maputo), Mozambique, when it was still a Portuguese colony, Ruy Guerra began writing film criticism at 17 while taking part at the same time in pro-independence movements and anti-racist activities -- he left the country at 19 for Paris. First, he enrolled in the two-year course at IDHEC (1952-54) for directing, but says he learned filmmaking by working on productions as assistant cameraman and assistant director. His first short films, Song for Crossing the Water (1952) and When the Sun Sleeps (1954), were made at IDHEC. At the same time, he took courses in acting at the Charles Dullin School at TNP and could be seen as an actor in Georges Rouquier's SOS Noronha (1956).

Moving on to Brazil, Guerra started but didn't finish two short films: Oros (1959) and Cavalo de Oxumaré (1960) -- but was on hand for others in the burgeoning Cinema Novo movement. He edited the Carlos Diegues episode in the omnibus film Cinco Vezes Favela (1962), credited by many as the film that sparked the movement, and acted in Flavio Migliaccio's Os Mendigos (1962). The breakthrough came with his first feature film, The Unscrupulous (1962), in which he applied French New Wave aesthetics to portray the bourgeois of Copacabana with its dismal milieu of indifference and countenance of sex and rape, blackmail and protection rackets, and other related crimes.

Guerra followed with a run of productions that made him a name as both a leader of Cinema Novo and a director capable of international productions. His Os Fuzis (The Guns, 1964), one of Cinema Novo's most important films, is extraordinary in that a sequel was made a decade later, A Queda (The Fall, 1976), in which a soldier who had fired on villagers during the time of government oppression is now himself a victim of exploitation as a worker on a Rio construction side. The Fall, co-directed by Nelson Xavier and a competition entry at the 1977 Berlinale, was hailed by critics as a modern parallel to the classic crime-and-punishment theme. His Os Deuses e Os Mortos (The Gods and the Dead, 1970) was another Cinema Novo milestone. His Sweet Hunters (1969), a French production, was shot in Panama.

When Mozambique declared its independence in the late 1970s, he returned there to participate in the founding of the National Institute of Cinema. His Mueda, Memoria e Massacre (Death, Memory and Massacre, 1979) was the first Mozambique feature film. Afterwards, he abandoned radical political statements to make a series of international co-productions in Latin America acclaimed for their aesthetic beauty and commercial entertainment quality: The Stolen Letter (1982), two screen adaptations of stories by Gabriel García Márquez's Erendira (1983) and The Story of Bela Palomera (1987), Malandro's Opera (1985), and Kuarup (1988), from a novel by Antonio Callado.

Ruy Guerra's Turbulence, based on a novel by singer/song-writer Chico Buarque, chronicles the existential nightmare of an anonymous first-person character who roams through the streets of a modern city. The setting is Brazil today, the protagonist "I" is awaked from a restless night by the ringing of the doorbell and the presence of a man in the peephole who strikes fear and uncertainty. Feeling provoked, the man sneaks away from his apartment to experience a panoply of dreams and hallucinations which unfold and reach far into the past -- mother, sister, friends, thieves, cops, dealers, marijuana growers ...

"Chico Buarque's book is so well known," maintains Guerra, "that it seems unnecessary to enunciate the power of the text, the skilled manipulation of its real and imaginary time, praise the precise portrait of its characters, or underline the accuracy of its dramatic trajectory -- in which the absurd is defined in our own commonplace-ness. The cinematic image will, I hope, as a film, come close to the literary sensation." 


\section{References}

\section{AWARDS}

Golden Palm: Dancer in the Dark (Denmark-France-Germany-Japan), director Lars von Trier

Grand Jury Prize: Guizi lai le (Devils on the Doorstep, China), director Jiang Wen

Jury Prize (ex aequo): Takhté siah (Blackboards, Iran-Italy-Germany-Japan), director Samira Makhmalbaf, and Sainger frän andra vainingen (Songs from the Second Floor, Sweden), director Roy Andersson

Best Actress: Björk in Dancer in the Dark (Denmark-France-Germany-Japan), director Lars von Trier

Best Actor: Tony Leung in In the Mood for Love (Hong Kong-China), director Wong Kar-wai

Best Director: Edward Yang, Yi Yi (A One and a Two ..., Taiwan/Japan)

Best Screenplay: John C. Richards, James Flamberg, Nurse Betty (USA), director Neil LaBute

Grand Technical Prize: Christopher Doyle \& Mark Li Ping Bing (cinematography), William Chang Suk-Ping (production design), In the Mood for Love (Hong Kong-China), director Wong Kar-wai

Camera d'Or (ex aequo): Djomeh (Iran-France), director Hassan Yekpatanah (Certain Regard section), Zamani barayé masti asbha (A Time for Drunken Horses, Iran), director Bahman Ghobadi (Directors Fortnight section)

Golden Palm, Short Film: Animo (Philippines), director Raymond Red

Cinéfondation:

First Prize: Five Feet High and Rising (USA), director Petyer Sollett

Second Prize (ex aequo): Kiss It Up to God (USA), director Caran Hartsfield, Kinu'ach (Dessert, Israel), director Amit Sakomski

Third Prize (ex aequo): Indien (India, Denmark), director Pernille Fischer Christensen, Cuôc Xe Dêm (Night Course, Vietnam) director Bui Thac Chuyên

International Critics (Fipresci) Awards:

Competition: Eureka (Japan-France), director Aoyama Shinji

Directors Fortnight: Zamani barayé masti asbha (A Time for Drunken Horses, Iran), director Bahman Ghobadi

"Un Certain Regard" Award:

Things You Can Tell Just by Looking at Her (USA), director Rodrigo Garcia

Ecumenical Award: Eureka (Japan-France), director Aoyama Shinji

\section{Author Information}

Ron HOLLOWAY (1933-2009) was an American critic, film historian, filmmaker and correspondent who adopted Europe as his home in the early fifties and spent much of his life in Berlin. He was an expert on the study of German cinema and against all odds produced, with his wife Dorothea, the journal German Film, keeping us up-to-date with the work of directors, producers and writers and the showing of German films around the world.

In 2007, Ron Holloway and his wife were awarded the Berlinale Camera Award. Ron also received the Bundesverdienstkreuz (German Cross of Merit), Polish Rings, Cannes Gold Medaille, the American Cinema Foundation Award, the Diploma for Support of Russian Cinema and an honorary award from the German Film Critics' Association.

Ron was also a valued contributor to Kinema for the past fifteen years. 